\title{
Perlindungan Hukum Terhadap Wisatawan Menurut Undang-Undang Nomor 10 Tahun 2009 Tentang Kepariwisataan
}

\author{
Firya Oktaviarni ${ }^{1}$ \\ Fakultas Hukum Universitas Jambi \\ Email: firyaoktaviarni@unja.ac.id
}

\begin{abstract}
Abstrak
Pariwisata merupakan sektor penyumbang devisa negara, sehingga diperlukan adanya pariwisata. Namun, ada beberapa kasus yang terjadi di tempat wisata seperti seorang wisatawan menjadi korban tenggelam, seorang wisatawan meninggal di lokasi wisata dan seorang wisatawan menjadi korban harga tiket masuk di lokasi wisata. Untuk itu, diperlukan perlindungan hukum terhadap wisatawan agar kerugian yang dialami tidak selalu dibabankan kepada wisatawan. Tujuan penelitian untuk mengetahui perlindungan hukum terhadap wisatawan menurut UndangUndang Nomor 10 Tahun 2009 Tentang Kepariwisataan. Metode yang digunakan yaitu penelitian yuridis normatif, bahan hukum berupa bahan hukum primer dan sekunder, penelitian dikumpulkan dengan studi kepustakaan dan teknik analisisnya normatif kualitatif
\end{abstract}

Kata Kunci : perlindungan hukum, wisatawan

\begin{abstract}
Tourism is the country's foreign exchange contributing sector, so tourism is needed. However, there are some cases that occur at tourist attractions such as a tourist being a sinking victim, a tourist dies at a tourist location and a tourist becomes a victim of the price of admission at tourist sites. For this reason, legal protection is needed for tourists so that losses suffered are not always given to tourists. The research objective is to find out the legal protection of tourists according to Law Number 10 of 2009 concerning Tourism. The method used is normative juridical research, legal material in the form of primary and secondary legal materials, research collected with literature study and qualitative normative analysis techniques
\end{abstract}

Keywords: legal protection, tourists

\section{PENDAHULUAN}

Indonesia adalah negara dengan potensi kekayaan alam baik flora dan fauna serta peninggalan purbakala, peninggalan sejarah, seni dan budaya sebagai sumber daya dan modal pembangunan kepariwisataan untuk meningkatkan taraf hidup, kemakmuran dan kesejahteraan rakyat sebagaimana terkandung dalam Pancasila dan Pembukaan Undang-Undang Dasar Negara Republik Indonesia Tahun 1945. Aktivitas Pariwisata di Indonesia merupakan salah satu penyumbang terbesar dalam meningkatkan devisa negara sebagai destinasi wisata baik untuk wisatawan asing maupun lokal.

Sesuai dengan rumusan pada Pasal 1 angka 3 Undang-Undang Nomor 10 Tahun 2009 tentang Kepariwisataan, pariwisata adalah berbagai macam kegiatan wisata dan didukung berbagai fasilitas serta layanan yang disediakan oleh masyarakat, pengusaha, pemerintah dan pemerintah daerah. Dalam Pasal 1 angka 5 Undang-Undang Nomor 10Tahun 2009 tentang Kepariwisataan menjabarkan daya tarik wisata adalah segala sesuatu yang memiliki keunikan, keindahan dan nilai yang berupa keanekaragaman kekayaan alam, budaya dan hasil buatan manusia yang menjadi sasaran atau tujuan kunjungan wisatawan. Daerah tujuan pariwisata yang selanjutnya disebut destinasi pariwisata adalah kawasan geografis yang berada dalam satu atau lebih wilayah administratif yang di dalamnya terdapat daya tarik wisata, fasilitas umum, fasilitas pariwisata, aksesibilitas serta masyarakat yang saling terkait dan melengkapi terwujudnya kepariwisataan.

Seperti halnya di Provinsi Jambi memiliki potensi kekayaan alam yang dapat dijadikan destinasi pariwisata, baik itu wisata alam, wisata sejarah, wisata kuliner maupun wisata hasil industri kreatif pengusaha pariwisata. Dengan kreativitas penduduk lokal, pengusaha pariwisata dan pemerintah, saat ini di Jambi sudah mempunyai destinasi pariwisata sendiri. Hampir disetiap Kabupaten di Provinsi Jambi memiliki destinasi pariwisata. Destinasi pariwisata yang bisa dikunjungi antara lain : Taman Rimba, Agro

\footnotetext{
${ }^{1}$ Dosen Fakultas Hukum Universitas Jambi
} 
Wisata, Pelabuhan Perahu Danau Sipin, Menara dan Jembatan Gentala Arassy, Taman Wisata Kampoeng Radja, Tugu Pers, Tugu Juang Jambi, Merangin Geopark (Kabupaten Merangin), Candi Muaro Jambi (Muaro Jambi) Citraland waterpark dan lain sebagainya. Dengan banyaknya obyek wisata tersebut, harus diimbangi dengan akses dan fasilitas yang disediakan di obyek wisata tersebut.

Selain penyediaan akomodasi, perlindungan sangat diperlukan untuk wisatawan di setiap destinasi pariwisata. Mengingat kegiatan pariwisata berintikan pengamanan terhadap keselamatan wisatawan, kelestarian dan mutu lingkungan, atau ketertiban dan ketentraman masyarakat, yang diselenggarakan berdasarkan ketentuan perundang-undangan yang berlaku. Apabila suatu negara tujuan wisata tidak dapat memberikan rasa aman, tidak tertib dan tidak dapat memberikan keselamatan dan pelayanan yang memadai bagi wisatawan, maka negara itu akan dijauhi oleh wisatawan dan ujung-ujungnya akan sangat mempengaruhi perkembangan pariwisata di negara tersebut. Adanya peningkatan kemajuan kepariwisataan nasional, yang ditandai dengan peningkatan jumlah wisatawan ke Indonesia, perlu dipertahankan dengan cara memberikan perlindungan hukum yang maksimal bagi wisatawan dengan menjaga keamanan dan keselamatan wisatawan yang bersangkutan dari kemungkinan-kemungkinan tindakan atau peristiwa yang merugikan. $^{2}$

Untuk menghasilkan daya tarik pariwisata di Provinsi Jambi dibutuhkan pendekatan baik dari undangundang dan regulasi serta penegakan hukum. Perlindungan wisatawan dalam bisnis pariwisata juga harus ditegakkan, mengingat semakin meningkatnya inovasi dalam bidang pariwisata di negara kita. Kerugian yang sering terjadi di obyek wisata cenderung selalu dibebankan kepada wisatawan dengan asumsi bahwa kerugian tersebut merupakan kelalaian wisatawan itu sendiri. Beberapa kasus yang belum lama ini terjadi di objek wisata karena kurangnya tingkat pengamanan dan keselamatan sehingga merugikan pengunjung sebagai konsumen baik secara fisik maupun materi. Seorang wisatawan asal Kabupaten Muaro Bungo menjadi korban tenggelam di salah satu objek wisata yang berada di danau Lubuk Beringin. ${ }^{3}$ Seorang wisatawan meninggal di lokasi wisata air terjun Sako Batang Merangin. ${ }^{4}$ Seorang wisatawan menjadi korban harga tiket masuk dan parkir yang mahal di lokasi wisata Danau Kerinci. ${ }^{5}$

Dari uraian dalam latar belakang di atas, dapat dirumuskan permasalahan hukum sebagai berikut: bagaimanakah perlindungan hukum terhadap wisatawan menurut Undang-Undang Nomor 10 Tahun 2009 Tentang Kepariwisataan?

Tujuan penelitian ini untuk mengetahui perlindungan hukum terhadap wisatawan menurut UndangUndang Nomor 10 Tahun 2009 Tentang Kepariwisataan.

\section{METODE PENELITIAN}

Tipe penelitian yang digunakan adalah penelitian yuridis normatif, penelitian ini menggunakan pendekatan perundang-undangan. Pendekatan perundangan-undangan adalah pendekatan yang dilakukan dengan menelaah semua undang-undang dan regulasi yang bersangkut paut dengan isu hukum yang ditangani. ${ }^{6}$

Bahan hukum yang digunakan berupa bahan hukum primer yaitu peraturan perundang-undangan baik yang berkaitan dengan naskah akademik maupun yang mengatur mengenai naskah akademik dan bahan hukum sekunder yang terdiri atas literature-literatur, hasil penelitian, makalah-makalah dalam seminar, jurnal, artikel-artikel dan bahan-bahan bacaan yang berkaitan dengan permasalahan yang diteliti serta bahan hukum tersier berupa kamus dan ensiklopedia hukum.

Dalam penelitian dikumpulkan dengan cara studi kepustakaan. Studi Kepustakaan dilakukan dengan cara mempelajari, membaca dan memahami buku-buku, peraturan perundang-undangan dan pendapatpendapat yang erat kaitannya dengan materi yang diteliti.

${ }^{2}$ Ni Made Novi Rahayu Widiastari A.A. Sri Indrawati, "Pengaturan Perlindungan Hukum Terhadap Wisatawan", Jurnal Ilmu Hukum, Vol. 01, No. 05, (Juli 2013) : 2.

${ }^{3}$ Hradesman Saragih, "Pengunjung Tewas Tenggelam Di Obyek Wisata Bungo", Berita Satu, (25 Juni 2018$)$ : 9.

${ }^{4}$ Henry Dede, "Seorang pengunjung Air Terjun Sako Batang Menrangin Tewas", Tribun Jambi, (19 Juli 2017$)$ : 11.

5 Heru Pitra, "Pungli di Objek Wisata Danau Kerinci-Disparbudpora Kerinci Enggan Bersuara", Tribun Jambi, (19 Juni 2018) : 9 .

${ }^{6}$ Peter Mahmud Marzuki, Penelitian Hukum, Kencana Prenada Media Group, Jakarta, 2011, hlm 24. 
Teknik analisis dalam penelitian ini adalah data yang diperoleh dianalisis secara normatif kualitatif yaitu menjabarkan dan menafsirkan data berdasarkan asas-asas, norma-norma, teori/doktrin ilmu hukum khususnya hukum pidana.

\section{HASIL DAN PEMBAHASAN \\ Perlindungan Hukum Terhadap Wisatawan Menurut Undang-Undang Nomor 10 Tahun 2009 Tentang Kepariwisataan}

Kepariwisataan (tourism) bukanlah hal yang baru di Indonesia. Kegiatan ini telah ditempatkan sebagai objek kebijakan nasional sejak pertama kali Indonesia menentukan kebijakan pembangunan. Sejak semula pemerintah Indonesia telah menyadari karakter khas dan sifat multidimensi dari kegiatan kepariwisataan, dan karena itu kebijakan kepariwisataan ditempatkan sebagai sub-kebijakan tersendiri, yaitu kebijakan kepariwisataan, namun dibawah bidang yang berbeda-beda tugas paling utama yang harus dilaksanakan oleh para pembuat kebijakan di suatu destinasi pariwisata adalah melakukan kegiatan "sadar wisata" yang melibatkan seluruh pemangku kepentingan. Pengertian "sadar wisata" di sini bukan berarti pemaksaan kepada para pemangku kepentingan untuk menerima begitu saja ketika wilayahnya dijadikan sebagai destinasi pariwisata. Kegiatan ini seharusnya ditujukan untuk mengidentifikasi seberapa besar kebutuhan masyarakat yang tinggal di destinasi pariwisata terhadap pengembangan kepariwisataan itu sendiri. Wisatawan pada umumnya tidak memiliki kepentingan jangka panjang terhadap kestabilan kehidupan sosial, budaya dan pelestarian lingkungan hidup di destinasi pariwisata karena mereka bukan pemilik wilayah tersebut. Lain halnya dengan penduduk setempat, mereka sangat bergantung kepada kualitas kondisi sosial, budaya dan pelestarian lingkungan hidup, karena merupakan pemiliknya dan memiliki hubungan psikologis dan historis yang sangat erat dengan destinasi pariwisata ${ }^{7}$.

Pariwisata selalu menjadi sektor yang terus dikembangkanpemerintah. DPR RI telah menetapkan UU No. 10 Tahun 2009 tentangKepariwisataan yang menggantikan UU No. 9 Tahun 1990. Secararegulatif, undang-undang tersebut bertujuan untuk mendorong usaha kecildan menengah agar dapat membantu terciptanya Sustainable TourismIndustry. Undang-undang sebelumnya dianggap tidak mampu untukmenjawab tantangan dan harapan ke depan bagi pariwisata Indonesia.Sektor pariwisata dapat dikatakan bersentuhan langsung denganmasyarakat dengan tingkat ekonomi yang paling bawah, karena merekamereka itu yang akan melakukan kontak langsung dengan para wisatawanasing. Untuk itulah UU No. 10 Tahun 2009 ini ditetapkan, sehingga parapengrajin, pemandu wisata, dan para pelaku wisata kecil dan menengahdapat dibina dan dikembangkan sesuai dengan aturan yang berlaku ${ }^{8}$.

Menurut Undang-Undang Republik Indonesia Nomor 10 Tahun 2009 Tentang Kepariwisataan dalam Pasal 1 angka 1 dan angka 2, Wisata adalah kegiatan perjalanan yang dilakukan oleh seseorang atau sekelompok orang dengan mengunjungi tempat tertentu untuk tujuan rekreasi, pengembangan pribadi, atau mempelajari keunikan daya tarik wisata yang dikunjungi dalam jangka waktu sementara. Wisatawan adalah orang yang melakukan kegiatan wisata.

Berdasarkan sifat perjalanan, lokasi di mana perjalanan dilakukan, wisatawan dapat diklarifikasikan sebagai berikut:

1. Wisatawan Asing (Foreign Tourist)

Orang asing yang melakukan perjalanan wisata, yang dating memasuki suatu negara lain yangbukan merupakan negara di mana ia biasanya tinggal. Wisatawan asing disebut juga wisatawan mancanegara atau disingkat wisman.

2. Domestic Foreign Tourist

Orang asing yang berdiam atau bertempat tinggal di suatu negara karena tugas, dan melakukan perjalanan wisata di wilayah negara di mana ia tinggal. Misalnya, staf kedutaan Belanda yang mendapat cuti tahunan, tetapi ia tidak pulang ke Belanda, tetapi melakukan perjalanan wisata di Indonesia (tempat ia bertugas).

\section{Domestic Tourist}

${ }^{7}$ Basuki Antariksa, Penegakan Hukum Pariwisata Di Dki Jakarta Sebagai Destinasi Pariwisata Internasional, Dinas Pariwisata dan Kebudayaan Provinsi DKI Jakarta, di Jakarta (paparan dilaksanakan pada tanggal 8 November 2011).:5.

8 Aditya Yuli, , Pariwisata Ditinjau Dari Aspek Hukum Merek (Studi Kasus City Branding Daerah Istimewa Yogyakarta Sebagai Daerah Tujuan Wisata Unggulan Di Indonesia), Jurnal Ilmiah Ilmu Hukum QISTI Vol. 5 No. 1 (Januari 2011 ): 51. 
Seorang warga negara suatu negara yang melakukan perjalanan wisata dalam batas wilayah negaranya sendiri tanpa melewati perbatasan negaranya. Misalnya warga negara Indonesia yang melakukan perjalanan ke Bali atau ke Danau Toba. Wisatawan ini disebut juga wisatawan dalamnegeri atau wisatawan nusantara (wisnu).

4. Indigenous Foreign Tourist

Warga negara suatu negara tertentu, yang karena tugasnya atau jabatannya berada di luar negeri, pulang ke negara asalnya dan melakukan perjalanan wisata di wilayah negaranya sendiri. Misalnya, warga negara Perancis yang bertugas sebagai konsultan di perusahaan asing di Indonesia, ketika liburan ia kembali ke Perancis dan melakukan perjalanan wisata di sana. Jeniswisatawan ini merupakan kebalikan dari Domestic Foreign Tourist

\section{Transit Tourist}

Wisatawan yang sedang melakukan perjalanan ke suatu negara tertentu, yang terpaksa mampir atau singgah pada suatu pelabuhan/airport/stasiun bukan atas kemauannya sendiri.

\section{Business Tourist}

Orang yang melakukan perjalanan untuk tujuan bisnis, bukan wisata, tetapi perjalanan wisata akan dilakukannya setelah tujuannya yang utama selesai. Jadi, perjalanan wisata merupakan tujuan sekunder, setelah tujuan primer yaitu bisnis selesai dilakukan. ${ }^{9}$

Pasal 4 Undang-Undang Nomor 10 Tahun 2009 Tentang Kepariwisataan, Kepariwisataan bertujuan untuk : meningkatkan pertumbuhan ekonomi, meningkatkan kesejahteraan rakyat, menghapus kemiskinan, mengatasi pengangguran, melestarikan alam, lingkungan, dan sumber daya, memajukan kebudayaan, mengangkat citra bangsa, memupuk rasa cinta tanah air, memperkukuh jati diri dan kesatuan bangsa danmempererat persahabatan antar bangsa.

Oleh karena itu, diperlukan perlindungan terhadap potensi wisata yang ada harus dapat dipertahankan, karena obyek wisata merupakan ciri khas suatu negara. Pengembangan faktor penunjang obyek wisata harus terus ditingkatkan dan diperhatikan agar Indonesia dapat bersaing dengan negara lain ${ }^{10}$. Peningkatan terhadap faktor penunjang akan memudahkan akses pengunjung untuk datang ke obyek-obyek wisata yang ada.

Jenis Usaha PariwisataDalam Pasal 14 ayat (1) Undang-UndangNomor 10 Tahun 2009 Tentang Kepariwisataan menjelaskan bahwa ruang lingkup jenis usaha Pariwisata meliputi:

a. Daya tarik wisata adalah usaha yang kegiatannya mengelola daya tarik wisata alam, daya tarik wisata budaya, dan daya tarik wisata buatan/binaan manusia.

b. Kawasan pariwisata adalah usaha yang kegiatannya membangun dan/atau mengelola kawasan dengan luas tertentu untuk memenuhi kebutuhan pariwisata.

c. Jasa transportasi wisata adalah usaha khusus yang menyediakan angkutan untuk kebutuhan dan kegiatan pariwisata, bukan angkutan transportasi regular/umum.

d. Jasa perjalanan wisata adalah usaha biro perjalanan wisata dan usahaagen perjalanan wisata. Usaha biro perjalanan meliputi usaha penyediaan jasa perencanaan perjalanan dan/atau jasa pelayanan dan penyelenggaraan perjalanan ibadah. Usaha agen perjalanan wisata meliputi usaha jasa pemesanan sarana, seperti pemesanan tiket dan pemesanan akomodasi serta pengurusan dokumentasi perjalanan.

e. Jasa makanan dan minuman adalah usaha jasa penyediaan makanan dan minuman yang dilengkapi dengan peralatan dan perlengkapan untuk proses pembuatan dapat berupa restoran, kafe, jasa boga, dan bar/kedai minuman.

f. Penyediaan akomodasi adalah usaha yang menyediakan pelayanan penginapan yang dapat dilengkapi dengan pelayanan pariwisata lainnya. Usaha penyediaan akomodasi dapat berupa hotel, vila, pondok wisata, bumi perkemahan, pesinggahan karavan, dan akomodasi lainnya yang digunakan untuk tujuan pariwisata.

9 Yusac L. Diyono, Materi Kuliah Introduction To Tourism (Pengantar Pariwisata), Untag Semarang, www.scribd.com. diakses 14 Oktober 2018.

${ }^{10}$ Sarsiti dan Muhammad Taufiq, Penerapan Perlindungan Hukum Terhadap Wisatawan Yang Mengalami Kerugian di Obyek Wisata (Studi di Kabupaten Purbalingga), Jurnal Dinamika Hukum Vol. 12 No. 1(Januari 2012): 28. 
g. Penyelenggaraan kegiatan hiburan dan rekreasi merupakan usaha yang ruang lingkup kegiatannya berupa usaha seni pertunjukan, arena permainan, karaoke, bioskop, serta kegiatan hiburan dan rekreasi lainnya yang bertujuan untuk pariwisata.

h. Penyelenggaraan pertemuan, perjalanan insentif, konferensi, dan pameran adalah usaha yang memberikan jasa bagi suatu pertemuan sekelompok orang, menyelenggarakan perjalanan bagi karyawan dan mitra usaha sebagai imbalan atas prestasinya, serta menyelenggarakan pameran dalam rangka menyebarluasakan informasi dan promosi suatu barang dan jasa yang berskala nasional, regional, dan internasional.

i. Jasa informasi pariwisata adalah usaha yang menyediakan data, berita, feature, foto, video dan hasil penelitian mengenai kepariwisataan yang disebarkan dalam bentuk bahan cetak dan/atau elektronik.

j. Jasa konsultan pariwisata adalah usaha yang menyediakan saran dan rekomendasi mengenai studi kelayakan, perencanaan, pengelolaan usaha, penelitian dan pemasaran di bidang kepariwisataan.

k. Jasa pramuwisata adalah usaha yang menyediakan dan/atau mengkoordinasikan tenaga pemandu wisata untuk memenuhi kebutuhan wisatawan dan/atau kebutuhan biro perjalanan wisata.

1. Wisata tirta merupakan usaha yang menyelenggarakan wisata dan olahraga air, termasuk penyediaan sarana dan prasarana serta jasa lainnya yang dikelola secara komersial di perairan laut, pantai, sungai, danau dan waduk.

m. Spa adalah usaha perawatan yang memberikan layanan dengan metode kombinasi terapi air, terapi aroma, pijat, rempah-rempah, layanan makanan/minuman sehat, dan olah aktivitas fisik dengan tujuan menyeimbangkan jiwa dan raga dengan tetap memperhatikan tradisi dan budaya bangsa Indonesia.

Undang-Undang Nomor 10 Tahun 2009 Tentang Kepariwisataan sudah mengatur tentang hak dan kewajiban wisatawan dan pengusaha pariwisata. Pasal 20 mengatur mengenai hak wisatawan, antara lain : informasi yang akurat mengenai daya tarik wisata, pelayanan kepariwisataan sesuai dengan standar, perlindungan hukum dan keamanan, pelayanan kesehatan, perlindungan hak pribadi, danperlindungan asuransi untuk kegiatan pariwisata yang berisiko tinggi. Sementara pada Pasal 25 mengenai kewajiban wisatawan, antara lain : menjaga dan menghormati norma agama, adat istiadat, budaya, dan nilai-nilai yang hidup dalam masyarakat setempat, memelihara dan melestarikan lingkungan, turut serta menjaga ketertiban dan keamanan lingkungan dan turut serta mencegah segala bentuk perbuatan yangmelanggar kesusilaan dan kegiatan yang melanggar hukum.

Pasal 22 Undang-Undang Nomor 10 Tahun 2009 Tentang Kepariwisataan hak-hak pengusaha pariwisata antara lain : mendapatkan kesempatan yang sama dalam berusaha di bidang kepariwisataan, membentuk dan menjadi anggota asosiasi kepariwisataan, mendapatkan perlindungan hukum dalam berusaha dan mendapatkan fasilitas sesuai dengan ketentuanperaturan perundang-undangan.

Sementara kewajiban pengusaha pariwisata menurut Pasal 26 antara lain: menjaga dan menghormati norma agama, adat istiadat, budaya, dan nilai-nilai yang hidup dalam masyarakat setempat, memberikan informasi yang akurat dan bertanggungjawab, memberikan pelayanan yang tidak diskriminatif, memberikan kenyamanan, keramahan, perlindungankeamanan, dan keselamatan wisatawan, memberikan perlindungan asuransi pada usaha pariwisata dengan kegiatan yang berisiko tinggi, mengembangkan kemitraan dengan usaha mikro, kecil dan koperasi setempat yang saling memerlukan, memperkuat, dan menguntungkan, mengutamakan penggunaan produk masyarakat setempat, produk dalam negeri, dan memberikan kesempatan kepada tenaga kerja lokal, meningkatkan kompetensi tenaga kerja melalui pelatihan dan pendidikan, berperan aktif dalam upaya pengembangan prasarana dan program pemberdayaan masyarakat, turut serta mencegah segala bentuk perbuatan yangmelanggar kesusilaan dan kegiatan yang melanggar hukum di lingkungan tempat usahanya, memelihara lingkungan yang sehat, bersih, dan asri, memelihara kelestarian lingkungan alam dan budaya, menjaga citra negara dan bangsa Indonesia melalui kegiatan usaha kepariwisataan secara bertanggungjawab dan menerapkan standar usaha dan standar kompetensisesuai dengan ketentuan peraturanperundang-undangan. Hak dan kewajiban Peraturan Daerah Kota Jambi Nomor 15 Tahun 2017 Tentang Penyelenggaraan Kepariwisataan pada Pasal 49, Setiap wisatawan berhak memperoleh :

a. Informasi yang akurat mengenai daya tarik wisata.

b. Pelayanan kepariwisataan sesuai dengan standar.

c. Perlindungan hukum dan keamanan.

d. Pelayanan kesehatan. 
e. Perlindungan hak pribadi.

Pasal 50 menyatakan Setiap pengusaha pariwisata berhak :

a. Mendapatkan kesempatan yang sama dalam berusaha di bidang kepariwisataan;

b. Membentuk dan menjadi anggota asosiasi kepariwisataan;

c. Mendapatkan perlindungan hukum dalam berusaha dan

d. Mendapatkan fasilitas sesuai dengan ketentuan peraturanperundang-undangan.

Pasal 53 menyatakan Setiap pengusaha yang menyelenggarakan usaha pariwisata wajib :

a. Menjaga dan menghormati norma agama, adat istiadat, budaya dan nilai-nilai yang hidup dalam masyarakat setempat;

b. Memberikan informasi yang akurat dan bertanggung jawab;

c. Memberikan pelayanan yang prima dan tidak diskriminatif;

d. Memberikan kenyamanan, keramahan, perlindungan keamanan, dan keselamatan wisatawan;

e. Memberikan perlindungan asuransi pada usaha pariwisata dengan kegiatan yang beresiko tinggi;

f. Mengembangkan kemitraan dengan usaha mikro, kecil, dan koperasi setempat yang saling memerlukan, memperkuat dan menguntungkan;

g. Mengutamakan penggunaan produk masyarakat setempat, produk dalam negri, dan memberikan kesempatan kepadatenaga kerja local;

h. Meningkatkan kopetensi tenaga kerja melalui pelatihan dan pendidikan;

i. Berperan aktif dalam upaya pengembangan prasarana dan program pemberdayaan masyarakat;

j. Turut serta mencegah segala bentuk perbuatan yang melanggar kesusilaan dan kegiatan yang melanggar hukum dilingkungan tempat usahanya;

k. Memelihara lingkungan yang sehat, bersih, dan asri;

1. Memelihara kelestarian lingkungan alam dan budaya;

$\mathrm{m}$. Menjaga citra daerah melalui kegiatan usaha pariwisata secara bertanggung jawab dan

n. Menerapkan standar usaha dan standar kompetensi sesuai dengan ketentuan peraturan perundangundangan.

Perlindungan hukum terhadap wisatawan masih rendah dengan timbulnya kerugian wisatawan di objek wisata baik terhadap diri maupun terhadap harta wisatawan itu sendiri. Seperti halnya kasus yang menimpa seorang wisatawan asal Kabupaten Muaro Bungo menjadi korban tenggelam di salah satu objek wisata yang berada di danau Lubuk Beringin dan seorang wisatawan meninggal dilokasi wisata air terjun Sako Batang Merangin. Ketentuan Pasal 20 huruf c dari undang-undang kepariwisataan menyatakan bahwa setiap wisatawan berhak memperoleh perlindungan hukum dan keamanan. Sesuai dengan Pasal 26 huruf d Undang-Undang Nomor 10 Tahun 2009 Tentang Kepariwisataan, Pengusaha pariwisata harus melaksanakan kewajibannya dalam memberikan kenyamanan, keramahan, perlindungan keamanan, dan keselamatan kepada wisatawan. Pasal 23 ayat (1) huruf a, berkewajiban menyediakan informasi kepariwisataan, perlindungan hukum, serta keamanan dan keselamatan kepada wisatawan.Untuk kasus seorang wisatawan menjadi korban harga tiket masuk dan parkir yang mahal di lokasi wisata Danau Kerinci, sesuai dengan Peraturan Daerah Kabupaten Kerinci Nomor 23 Tahun 2011 Tentang Retribusi Jasa Usaha.

Dalam Undang-Undang Nomor 10 Tahun 2009 Tentang Kepariwisataan mengatur tentang sanksi adminstratif untuk wisatawan dan pengusaha pariwisatayang terdapat dalam Pasal 62 yang menyatakan bahwa: (1) Setiap wisatawan yang tidak mematuhi ketentuan sebagaimana dimaksud dalam Pasal 25 dikenai sanksi berupa teguran lisan disertai dengan pemberitahuan mengenai hal yang harus dipenuhi. (2) Apabila wisatawan telah diberi teguran sebagaimana dimaksud pada ayat (1) dan tidak diindahkannya, wisatawan yang bersangkutan dapat diusir dari lokasi perbuatan dilakukan.

Sanksi administratif juga diatur dalam Peraturan Daerah Kota Jambi Nomor 15 Tahun 2017 Tentang Penyelenggaraan Kepariwisata Pasal 59

(1) Pengusaha Pariwisata yang tidak memenuhi ketentuan sebagaimana dimaksud dalam Pasal 42 ayat (1), Pasal 43ayat (2), Pasal 53 dan Pasal 57 ayat (5) dikenakan sanksi administrasi berupa :

a. Teguran tertulis;

b. Pembatasan kegiatan usaha;

c. Pembekuan sementara kegiatan usaha; dan

d. Pencabutan TDUP. 
(2) Ketentuan lebih lanjut tentang tata cara pelaksanaan sanksi administrasi diatur dengan peraturan walikota

Dalam Pasal 63 Undang-Undang Nomor 10 Tahun 2009 Tentang Kepariwisataan, dinyatakan bahwa :

(1) Setiap pengusaha pariwisata yang tidak memenuhi ketentuan sebagaimana dimaksud dalam Pasal 15 dan/atau Pasal 26 dikenai sanksi administratif.

(2) Sanksi administratif sebagaimana dimaksud pada ayat (1) berupa:

a. teguran tertulis;

b. pembatasan kegiatan usaha; dan

c. pembekuan sementara kegiatan usaha.

(3) Teguran tertulis sebagaimana dimaksud pada ayat (2) huruf a dikenakan kepada pengusaha paling banyak 3 (tiga) kali.

(4) Sanksi pembatasan kegiatan usaha dikenakan kepada pengusaha yang tidak mematuhi teguran sebagaimana dimaksud pada ayat (3).

(5) Sanksi pembekuan sementara kegiatan usaha dikenakan kepada pengusaha yang tidak memenuhi ketentuan sebagaimana dimaksud pada ayat (3) danayat (4).

Penerapan sanksi pidana terdapat dalamPasal 64Undang-Undang Nomor 10 Tahun 2009 Tentang Kepariwisataan:

(1) Setiap orang yang dengan sengaja dan melawan hukum merusak fisik daya tarik wisata sebagaimana dimaksud dalam Pasal 27 dipidana dengan pidana penjara paling lama 7 (tujuh) tahun dan denda paling banyak Rp10.000.000.000,00 (sepuluh miliar rupiah).

(2) Setiap orang yang karena kelalaiannya dan melawan hukum, merusak fisik, atau mengurangi nilai daya tarik wisata sebagaimana dimaksud dalam Pasal 27 dipidana dengan pidana penjara paling lama 1 (satu) tahun dan/atau denda paling banyak Rp5.000.000.000,00 (lima miliar rupiah).

Menurut Peraturan Daerah Kota JambiNomor 15 Tahun 2017 Tentang Penyelenggaraan Kepariwisata Pasal 61, menyatakan:

(1) Setiap orang atau badan yang melanggar ketentuan dalam Pasal 54 dan Pasal 55 diancam pidana kurungan paling lama 6 (enam) bulan dan denda paling banyak Rp.50.000.000,- (Lima Puluh Juta Rupiah).

(2) Tindak pidana sebagaimana dimaksud pada ayat (1) merupakan pelanggaran. Ketentuan sebagaimana dimaksud pada ayat (1) dan ayat (2) tidak mengurangi ancaman pidana yang ditetapkan dalam ketentuan peraturan perundang-undangan mengenai lingkungan hidup, benda cagar budaya dan undang-undang lainnya.

\section{SIMPULAN}

Perlindungan hukum terhadap wisatawan sudah diatur dalam Undang-Undang Nomor 10 Tahun 2009 Tentang Kepariwisataan maupun dalam Peraturan Daerah Kota Jambi Nomor 15 Tahun 2017 Tentang Penyelenggaraan Kepariwisataan. Pelaksanaan undang-undang mengenai pariwisata di Indonesia harus memperhatikan perlindungan hukum terhadap wisatawan sebagai pengguna jasa pariwisata di Indonesia. Oleh karenanya diperlukan pengaturan yang signifikan terhadap wisatawan dimulai segi sarana dan prasarana, standar keamanan dan keselamatan baik oleh pemerintah maupun oleh swasta, yang memperhatikan aspek yuridis dan kepastian hukum.

\section{DAFTAR PUSTAKA}

\section{Jurnal}

Aditya Yuli, Pariwisata Ditinjau Dari Aspek Hukum Merek (Studi Kasus City Branding Daerah Istimewa Yogyakarta Sebagai Daerah Tujuan Wisata Unggulan Di Indonesia), Jurnal Ilmiah Ilmu Hukum QISTI Vol. 5 No. 1 (Januari 2011): 51.

Ni Made Novi Rahayu Widiastari A.A. Sri Indrawati, Pengaturan PerlindunganHukum Terhadap Wisatawan, ,eJurnal Ilmu Hukum, Kerta SemayaVol. 01, No. 05, (Juli 2013): 2. 
Sarsiti dan Muhammad Taufiq, Penerapan Perlindungan Hukum Terhadap Wisatawan Yang Mengalami Kerugian di Obyek Wisata (Studi di Kabupaten Purbalingga), Jurnal Dinamika Hukum Vol.12 No.1 (Januari 2012): 28.

Yusac L. Diyono,Materi KuliahIntroduction To Tourism( Pengantar Pariwisata), UNTAG Semarang,www.scribd.com

\section{Makalah}

Basuki Antariksa, Penegakan Hukum Pariwisata Di Dki Jakarta Sebagai Destinasi Pariwisata Internasional, Dinas Pariwisata dan Kebudayaan Provinsi DKI Jakarta, di Jakarta (paparan dilaksanakan pada tanggal 8 November 2011).:5.

\section{Surat Kabar}

Hardesman Saragih, pengunjung tewas tenggelam di obyek wisata Bungo, Berita Satu,(25 Juni 2018).

Henry Dede, Seorang pengunjung Air Terjun Sako Batang Menrangin Tewas, Tribun Jambi,(19 Juli 2017).

Heru Pitra, Pungli di Objek Wisata Danau Kerinci-Disparbudpora Kerinci Enggan BersuaraTribun Jambi,(19 Juni 2018). 